\title{
The Thinking of La Salewangeng to Tenri Ruwa in Wajo Kingdom of South Sulawesi
}

\author{
Bustan* \\ Department of History Education, \\ Faculty of Social Science \\ Universitas Negeri Makassar \\ Makassar, Indonesia \\ bustan@unm.ac.id
}

\author{
Fitriani \\ Department of History Education, \\ Faculty of Social Science \\ Universitas Negeri Makassar \\ Makassar, Indonesia \\ fitrianismanda@gmail.com
}

\author{
Mustari Bosra \\ Department of History Education, \\ Faculty of Social Science \\ Universitas Negeri Makassar \\ Makassar, Indonesia \\ mustaribosra@unm.ac.id
}

\begin{abstract}
This research aims to describe the background and results of la Salewangeng to Tenri Ruwa Arung Matoa Wajo XXX. So did the influence of his thinking on the condition of the Kingdom of Wajo. The results showed that the thinking of La Salewangeng To Tenri Ruwa was influenced by several factors, namely; first, the family environment inspired his father's story about the thoughts and struggles of his grandfather La Taddamparek Puang Ri Maggalatung. Second, the unstable political living conditions of the Wajo Kingdom due to the VOC's invasion with its allies and the dispute over territorial boundaries. Third, the deteriorating state of the economy resulted in famine and poverty. The results of $\mathrm{La}$ Salewangeng To Tenri Ruwa's thinking include four areas, namely; first, the thinking in the field of state politics is open and democratic. Second, economic thinking, triggering a cooperative-shaped economy using the concept of save-pimjam capital for the people under the name Geddong Yassiwajori. Third, the thought of indigenous fields and social pranata. The four thoughts of the field of law and the judiciary are to apply the principle of legal equality in the judiciary without distinguishing status. The thought of La Salewangeng To Tenri Ruwa influenced the condition of the Wajo Kingdom in three aspects, namely political, social and economic. This research concluded, that the thought of La Salewangeng To Tenri Ruwa is still relevant as a guideline for the younger generation of Bugis Makassar people in South Sulaewsi and specifically Wajo Regency. This research is a descriptive study using historical methods, through measures namely; (1) heuristics, (2) criticism, (3) interpretation, and (4) historiography.
\end{abstract}

Keywords: Thoughts, La Salewangeng To Tenri Ruwa, Wajo Kingdom

\section{INTRODUCTION}

The Kingdom of Wajo was a further kingdom of the Cinnotabi Kingdom formerly led by a Batara. But after batara wajo xxx named La Pateddungi Tosamallangi died there was a power vacuum in Wajo. The indigenous figures Ranreng, Arung Mabbicara, and matowa Limpo agreed to appoint a king in wajo land named Arung Matoa. The election of Arung Matoa was conducted through the deliberations of indigenous figures [1]. Previous opinions were supported by statements submitted by Sritimuryati [2] which states that after the murder of La Pateddungi Tosamallangi by the Wajo people in the middle of the forest located east of the Capital of Wajo Kingdom. At that time the Wajo Kingdom experienced a power vacuum that caused the system of government in Wajo to change. King Wajo is no longer called Batara, but changed to Arung Matoa.

The condition of the Wajo Kingdom during the reign of La Salewangeng To Tenri Ruwa is still under colonized. This was because the Wajo Kingdom at that time entered into a subordinate area of the Bone Kingdom. The Wajo Kingdom was previously an equal kingdom and later became a subordinate kingdom. At that time La Salewangeng To Tenri Ruwa also built a cooperative-like building called Geddonge or ammunition building in Tosora [3]

La Salewangeng To Tenri Ruwa became Arung Matowa in Wajo replacing La Tenriweru Puwananna Sangaji who reigned three years (1712-1715). La Salewangeng To Tenri Ruwa is a king who has good planning, many Wajo people are rich, rice crops are increasing. Traders are lucky to trade. However, it is not yet known what strategy was used during his reign mainly in improving the economy of his people even though in the colonized state of La Salewangeng To Tenri Ruwa during the reign said that nothing could be passed on to his posterity except his admonition. There are many wise admonitions from him. The admonition is written in the leaflets of the manuscript of several figures of the Arung Matoa family in Wajo. Based on the results of previous research and the results of the initial interview of researchers, there are still many admonitions that have not been explained. So this research is important to uncover the admonitions of Arung Matoa La Salewangeng To Tenri Ruwa. As one of the local wisdom of Wajo Regency. In addition, there is still a lack of research on the history of thought or intellectuals, especially the history of thought during the Wajo Kingdom.

By Mappangara [4] based on historical records of the Wajo Kingdom during the period until the collapse of nine scholars who had been in the Kingdom of Wajo. Bugis Wajo scholars are noted to have been influential figures. Each scholar in the Kingdom of Wajo in his time had characteristics. Of the nine Bugis Wajo scholars there are four scholars who are arung matoa.

According to Asse, that [5] One of the scholars in wajo kingdom who also played Arung Matoa reigned long enough is La Salewangeng To Tenri Ruwa Arung Matoa to 
XXX. Arung Matoa as a figure who plays a role in the system of government, economy and society in wajo kingdom. His reign is almost 20 years old. One of his efforts was to strengthen the wajo government's weaponry in order to prepare for war with the Bone and Dutch kingdoms. However, there has been no specific explanation as to how efforts were made to build or prepare the war equipment and why La Salewangeng To Tenri Ruwa long reigned in the Kingdom of Wajo.

By Darmawati [6] the characteristics of a character are seen as scholars or tosulesanna there are four namely; first, molaiwi there is naparapi meaning to be able to follow the conversation. Second, the incense of breath means being able to welcome the conversation and overcome it. Third, matui there is nasitinaja means to be able to arrange a targeted conversation, taroi gau riakuannae means to have a proper or appropriate conversation.

This research is important as one of the efforts to perpetuate the figure, thought and struggle of the figure or king during the Wajo Kingdom as an effort to increase the reference about the history of intellectual figures in the kingdom in South Sulawesi in particular and regrow the historical memory of the nation's younger generation against the thoughts and struggles of figures in the kingdom so that the history of thought, struggle and figure of kings or figures is not snared and lost from the collective memory of the people or the younger generation of the nation.

\section{METHOD}

The type of research used in this study is a type of historical or historical research. This research is a descriptive research analysis of historical sources, is an implementation of the stages of activities involved in historical methods according to Madjid and Hamid [7] namely heuristics, criticisms, interpretations, and historiog.raphy

a. Heuristics

Heuristics is the first step in historical research activities that include the activities of finding, knowing and collecting data. The places to search for library data are Makassar State University Public Library, History Education Department of Makassar State University, Makassar Public Library, Makassar Multimedia Library, Makassar City Cultural Value Preservation Hall Library, Hasanuddin University Faculty of Cultural Sciences Library, Hasanuddin University Public Library, South Sulawesi Provincial Library and Archives, Wajo District Library and Archives, Al Markaz Al Islam Public Library Wajo Regency, Ekomuseum in Pammana Wajo Regency, Wajo District Education and Culture Office, and Wajo District Museum.

\section{b. Source Criticism}

The next stage after the collection of historical sources is the criticism of the source. The source criticism is an attempt to test the sources and data found during the research process in the field. The second step is divided into two types of criticism, namely intenal criticism and external criticism. Internal criticism is an attempt to test the authenticity or authenticity of the source obtained by whether the author, material, letters and data sources are contemporaries with historical events examined. Meanwhile, external criticism aims to see the credibility (truth of the source) or to select information obtained from historical sources whether it is credible or not. Testing of data source authenticity in the form of written documents is done by paying attention to the time, place, and material of the source writing. While the credibility of written sources is known from historical facts.

c. Interpretation

Interpretation is the third stage conducted in historical research at this stage as researchers seek to compare, interpret data obtained in the field to obtain objective data. Researchers formulated statements about the facts revealed in the study literature.

\section{d. d. Historografi}

Historiography is the last stage in historical research that is writing history by presenting data and facts that have been formulated in the form of a complete presentation. Historiography is the presentation of research data as it is synthesized and written in the form of historical stories. The history of the thought of the character La Salewangeng To Tenri Ruwa after going through the three stages of writing the history of researchers synthesizes and writes based on the results of analysis from several primary and secondary library sources that the author obtained from several references.

\section{RESULTS AND DISCUSSION}

\section{A. Thought of La Salewangeng To Tenri Ruwa As Arung Matoa Wajo XXX}

Based on several sources of reference that the researchers wrote and narrated from the four areas of thought of La Salewangeng To Tenri Ruwa researchers concluded that there is a thought of La Salewangeng To Tenri Ruwa that is purely from the results of his thoughts and his thoughts that are local wisdom inherited from his predecessors.

\section{a. Political Field}

Political thought is all the fruit of the mind related to the relationship of cooperation to gain mutual advantage. Based on the results of the search researchers obtained information that during the reign of arung matoa to XXX La Salewangeng To Tenri Ruwa Wajo Kingdom has done some cooperation with several local kingdoms in South Sulawesi. Here are the names of the kingdoms that have cooperated with the Wajo Kingdom and the purpose of its cooperation during the reign of La Salewangeng To Tenri Ruwa;

\section{1) Bone Kingdom Relationship with Wajo Kingdom}

According to Djemma and Sabbang [8] The cooperation between Arungmpone and La Salewangeng To Tenri Ruwa took place when the condition of the Wajo Kingdom geddong was filled with bedil and tin weapons At the same time La Salewangeng To Tenri Ruwa visited the house of taudeceng and nahkoda ship in Wajo Kingdom to check the amount of bullet and lead supplies and check the contents of the geddong every real limpo was full. When he learned that wajo kingdom's war preparations were adequate, La Salewangeng To Tenri Ruwa met king Bone to ask permission to teach knowledge on how to use the correct 
weapons to the Wajo Kingdom. La Salewangeng To Tenri Ruwa reasoned that the knowledge was a memento of King Bone and that King Bone avoided siri or shame when there was a dispute in Gowa and the Wajo people who became tellupoccoe messengers did not know how to use weapons.

The Wajo Kingdom and bone kingdom also cooperated during the VOC's invasion with its allies against the Wajo Kingdom which took place upon learning La Maddukeleng wanted to land in wajo kingdom precisely peneki territory in March 1736. La Maddukelleng gained protection from a Bone nobleman named Daeng Mamumtuli Arung Kaju with the escort of approximately three thousand Bone's troops. The help of daeng mamumtuli arung kaju caused La Maddukelleng to defeat Tellupoccoe's forces. [8].

\section{2) Gowa Kingdom Relationship with Wajo Kingdom}

According to Palloge [9] the relationship between the Kingdom of Gowa and the Wajo Kingdom occurred, due to the similarities of interests up to the XVII century. Wajo Kingdom helped gowa kingdom several times when attacked by the Dutch. Wajo at that time was under the domination of the Kingdom of Gowa. The Kingdom of Gowa expanded to expand its territory and power influence until the beginning of the XVII century. Wajo Kingdom's involvement in the Tellupoccoe alliance caused gowa kings to be disillusioned with the Wajo people and carried out several attacks on the Wajo Kingdom. However, relations between the two kingdoms improved again when the Kingdom of Gowa was attacked by the Bone Kingdom and the Kingdom of Soppeng with the Dutch in 1660-1667. The Wajo people helped the Kingdom of Gowa as a sign of the Wajo people's loyalty to the Kingdom of Gowa [10].

During the reign of La Salewangeng To Tenri Ruwa there was also a cooperative relationship between the Kingdom of Gowa and the Kingdom of Wajo which aimed to make a cooperation agreement to help each other on a condition of enabling to carry out attacks and expel the Dutch from Makassar. The treaty meeting represented by Lamadukelleng of The Kingdom of Wajo and La Mapasepe Karaeng Bontolangkasa a speaker of the Kingdom of Gowa [11].

Based on his struggle during his reign La Salewangeng To Tenri Ruwa was intended into the category of democratic leadership, evidenced when being arung matoa La Salewangeng To Tenri Ruwa held monthly deliberations with Petta I Wajo to discuss and think about all matters related to the goodness and safety of the people of Wajo Kingdom [12].

Another feature of La Salewangeng To Tenri Ruwa's leadership is that everything done in its time always places hope and prayer to Allah SWT. This is in accordance with the belief system of the Wajo people in the 17th century who already knew the religion of Islam knowing the teachings of tawhid oriented towards the One True God. In addition, it can also be seen from the admonitions he delivered during his reign and the contents of lontara Akkarungeng Wajo I which discusses La Salewangeng To Tenri Ruwa often found the term puweng Allataala or Allah SWT [12].

\section{b. Economics}

According to Duli [3] efforts to improve the economy of Wajo Kingdom were carried out in several ways including building a multipurpose building called Geddong Yassiwajori in 1718. The building is located in three limpo or areas namely in Tolotenreng, Tua and Bentengpola right in the center of Wajo Kingdom, Tosora. Geddonge during the kingdom enabled the storage of war tools and produce of the Wajo Kingdom.

Evidence of the building's current existence can be seen from the remains of its ruins in Tosora. There is an $8 \mathrm{~m}$ front wall side and a cannon frame that has been removed from the bow. Its role as a multifunctional building signifies the role of the building for the Wajo Kingdom in the 17th century. Reviewed in spatial terms geddonge located close to the west coast of the lake adjacent to the pier [13]. The concept of Geddong Yassiwajori's work designed by La Salewangeng To Tenri Ruwa in Wajo Kingdom bears a resemblance to the cooperative working concept designed by Bung Hatta. Together aim to achieve the necessity of living together to ease the burden of another on the basis of the principle of help-help and complementing shared needs, as well as improving the process of distributing goods from one place to another. If the process of distribution of goods is hampered it will have an impact on the increase in the price of goods that can incriminate the small people.

The concept of cooperatives in Indonesia is based on the economic system of the popular economy established by Bung Hatta on the basis of kinship. The stated in article 33 of the 1945 Constitution which states that the economy is structured as a joint venture based on family azas, production branches that are important to the state and control the lives of the people controlled by the state, the water earth and all the natural wealth contained in it is controlled by the state and used for the great prosperity of the people [14]. Based on the statement of cooperative concept in accordance with the purpose of La Salewangeng To Tenri Ruwa established Geddong Yassiwajori during his reign.

\section{c. Indigenous and Social Pranata}

Based on the contents of the manuscript of lontara Akkarungeng I [15] obtained information that during his life La Salawangeng To Tenri Ruwa arung matowa Wajo to XXX conveyed many teachings about social customs and pranata. It is noted that there are several customary values and social links that can be used as guidelines in behavior that are still relevant applied by the community today. The teachings presented by La Salawangeng To Tenri Ruwa stem from his life experiences and life habits. The following are some teachings of La Salawangeng To Tenri Ruwa regarding the traditional values and social pranata in behavior that are the result of pure thought:

\section{a) Intelligence}

"eppa tanranna tauwe namacca, seuwani malempui na mateteq, maduwanna makurang caii, matelunna maraddeqi ri gauq sitinajae, maeppana makurang pau-pauwi ri padanna rupa tau" [15].

It means; 
"The four signs are owned by a smart person, the first is honest and firm, the second is less angry, the third is on reasonable behavior, the fourth is less speaking to his neighbor".

The above statement means that there are four characteristics of a person called smart i.e. having traits such as being honest and assertive, rarely angry, always doing appropriate, and speaking less towards others. The so-called smart is a man who is generous in teaching his knowledge regardless of differences in beliefs, tribes, languages, and customs.

\section{b) Honesty}

"Naiyya ponna lempuk e tellu mpuwangengngi; seuwai iyapa napuadai kadopi molai, maduwanna iyyapa napogauk $i$ kadopi lewuriwi, ri munripi tau e, matellunna tennaenreki e waramparang ripalolo tennasakkarengngi ada-ada maddiolona" [15].

It means;

"As for the two sources of honesty, namely just saying the word when able to carry it out, the second is just doing an act when able to account for it".

c) Moral

"Pitumpuangengngi ripogauk nacaca Dewata Seuwae.

1) Takkaborok i tauwe nadek tobakenna.

2) Balik bella $i$ tauwe nadek tobakenna. Naiyya riyasengnge balikbella tau mappasilettu-lettukengngi ada, nasabak mebbui assisalangngeng namarang siuno tauwe, masero maneng nagelli puangta Dewata Seuwae

3) Mappau ri boko

4) Tempedding ripoada anu nacaccae tauwe

5) Riunoi tauwe

6) Rikira-kira i repona tauwe iyarega waramparanna tauwe.

7) Mappangkak i tauwe

Iyanaro tau pallipakengngi pasengnge torigellinna Dewata Seuwae, tessalamakni ri linok lettu ri aherak" [16].

It means;

The agreement of matoa tani in Wajo states that there are seven kinds of things that are done unloved by the One True God

1) It is forbidden to do so because he is not apunced.

2) It is forbidden to lie, nor can it bepun. A person is said to be lying when they say an un truthful word to another. He caused a dispute until there was an altercation and killed each other. This is hated by the one-of-one god.

3) Likes to talk in the background

4) We can't talk about something people don't like.

5) We must not intend to evil or kill a family, someone's wife.

6) No greed is prohibited

7) It is forbidden to be proud or behave

The above statement means that there are seven despicable attributes or deeds that are not forbidden by the One True God in this world until the hereafter, namely the first of the second takabur nature of lying. All three traits speak of the ugliness of others in hindsight. The fourth talks about things that are not bik to others. The fifth killed his family or someone else. The sixth steals or takes which is not his right. The seven like to be proud or make fun of others.

\section{d) Leadership}

"Eppa tanranna arung mangkauk e malempuk, seuwani malampek addampengeng, namaraja paccarinnanna, maduwannna tekkacinna-cinnai,matellunna mapatoi mappetangnga ripabbicaranna, maeppana maelorengi pallaonruma" [15].

\section{It means;}

"Four signs of arung who reigns honestly in his government, the first is forgiving and affectionate, the second has no desire, diligently asks the opinion of the royal adviser, the fourth is happy with the agricultural problem".

The above statement means that the characteristics of an honest king are the first four that have the easy nature of forgiving the faults of others and compassionate to others. Both are not easily affected or consider something before making a decision. Third if you want to decide something often ask for consideration to his royal advisers. The fourth loves activities in agriculture.

e) Perjuangan dan Keberanian

"naiya riyasengnge tau sugi maeloqpi rugi waramparang ri tanae, napasidapiri wanuwana waramparang teppaulle" [15]. It means

"The wealthy are the one who will lose property in the land to help his land with his property."

The above statement means that the character of a person called a rich man is one who is willing to suffer losses for his land and provide assistance at the expense of his property for the benefit of his country or his kingdom.

\section{d. Legal and Judicial Fields}

The pure thought of La Salewangeng To Tenri Ruwa in the field of law and justice in the form of triggering and implementing for the first time the death penalty in Wajo Kingdom and there are some admonitions concerning how to uphold the judiciary of the law. While his thoughts in the field of law and judiciary are local wisdom inherited from his predecessor in the form of the application of punishment by upholding human rights and enforced firmly. According to Lontara Akkarungeng Wajo I La Salewangeng To Tenri Ruwa is arung matoa who began to apply the death penalty in Wajo Kingdom. Here are some statements of admonition submitted by La Salewangeng To Tenri Ruwa regarding the thinking of the law and the judiciary:

Naiyya bicarae tekke anak tekke eppo tekke siajing temmappe ininnawa tenri atau tenri abi. Bicarae ri bicara maneng ri sesena anu mallari adek".

It means: 
"Talk or custom of childlessness, no family, no choice of love both right and left, customary talk solves all problems based on customary decisions" [16].

The above statement stipulates that a joint or customary decision will not be changed if it is deemed to have no errors in its designation or is still relevant to be re-enacted. Indigenous decisions are decisions made for the common good. Not looking at anyone who breaks the law will still be upheld and that person should still be tried.

\section{CONCLUSION}

The results of La Salewangeng To Tenri Ruwa arung matoa Wajo XXX include four things: (a) political thinking in the form of state politics that is open to other kingdoms aimed at rallying the forces of war preparation against vocDutch and allies (b) the thinking in the field of economics is to trigger an economy that has a cooperative-like working system called Geddong Yassiwajori to strengthen the ecostate of wajo kingdom and reshape the governing control board called tiga matoa (matoa petani , merchant matoa and fisherman's matoa) as well as admonitions on things that can damage agriculture: (c) thoughts in the field of customs and social pranata include teachings or admonitions derived from life experiences or life habits that can be used as relevant life guidelines applied today namely regarding intelligence, honesty, morals, and leadership and struggle, and courage: (d) thinking in the field of law and justice based on customary rules as guidelines of life and upholding human rights.

The influence of La Salewangeng To Tenri Ruwa's thinking on the condition of the Wajo Kingdom is: (a) the political impact of the Wajo kingdom became strong in terms of preparation of war or weaponry against the VOC and its allies, the Wajo people were able to use weapons, and La Maddukelleng managed to expel the VOC and its allies from the Wajo Kingdom: (b) the social impact of the Wajo people returned to prosperous life, character values were formed against the Wajo people since the time of the kingdom and many Wajo people became : (c) economic impacts include agricultural products and wajo people's farms increase, the establishment of geddonge buildings or buildings that have a co-operative capital storage system in the Wajo Kingdom, and the ons of free trade in the Kingdom of Wajo.

\section{ACKNOWLEDGMENT}

Thank you very much to the Chancellor of the Universitas Negeri Makassar and the Dean of the UNM Faculty of Social Sciences who have provided funding and opportunities for us to conduct research, so that the writing from the results of this study can be completed.

\section{REFERENCES}

[[1] Z. Hijrah, “ Kerajaan Wajo pada masa pemerintahan Arung Matoa I La Palewo To Palipuk (1474-1481),” Makassar, 2014.

[2] Sritimuryati, "Kepemimpinan dan Ajaran-ajaran Lataddampare Puang Ri Maggalatung sebagai Arung Matoa Wajo IV,' Sritimuryati. 1999. Kepemimpinan dan Ajaran-ajaran Lataddampare Puang Ri Maggalatung sebagai Arung Matoa Wajo IV. Laporan Penelitian Sejarah dan Nilai Tradisional Su
Departemen Pendidikan dan Kebudayaan Direktorat Jenderal Kebudayaan, Makassar, 1999.

[3] A. Duli, "Peranan Tosora sebagai bandar Perdagangan Kerajaan Wajo Abad XVI-XIX," Jurnal Walennae, vol. 12, no. 2, pp. 143$158,2010$.

[4] S. Mappangara, Ensiklopedi Sejarah Sulawesi Selatan Sampai Tahun 1905, Makassar: Mappangara, S. 2004. Ensiklopedi Sejarah Dinas Kebudayaan dan Pariwisata Provinsi Sulsel, 2004.

[5] A. Asse, Mengenal Objek Wisata Sejarah dan Cagar Budaya di Kabupaten Wajo, Sengkang: BAPD Wajo, 2000.

[6] B. Darmawati, "Makna serta Konservasi Religi dan hukum terhadap ada Sulesana Ugie Masagalae," Jurnal Bunga Rampai, vol. 34, no. 6, pp. 243-272, 2017.

[7] M. S. Madjid dan A. R. Hamid, Pengantar Ilmu Sejarah, Yogyakarta: Ombak, 2015

[8] S. A. Djemma dan Sudirman Sabbang, Djemma, S, A. danSejarah dan Perjuangan Lamaddukelleng Arung Matoa Wajo-Sultan Pasir, Sengkang : Lampena Intimedia, 2010.

[9] A. Palloge, Sejarah Kerajaan Tanah Bone Masa Raja Pertama dan Raja-Raja Kemudiannya sebelum Masuknya Islam sampai Terakhir, Makassar: Yayasan Al Muallim, 2006.

[10] S. Mappangara, "Perjanjian Tellumpoccoe Tahun 1582: Tindak Balas Kerajaan Gowa terhadap Persekutuan Tiga Kerajaan di Sulawesi Selatan," Mappangara, S. 2014. Perjanjian Tellumpoccoe Tahun 1582: Tindak Balas Kerajaan Gowa terhadap Persekutuan Jurnal Pendidikan Sains Sosial dan Kemanusiaan, vol. 7, no. 1, pp. 43-54, 2014.

[11] A. D. Patunru, Sejarah Wajo, Yogyakarta: Yayasan Kebudayaan Sulawesi Selatan dan Tenggara, 1964

[12] Lontara Sukkuna Wajo, BPAD Sulsel Koleksi Dinas Perpustakaan dan Kearsipan Kota Makassar.

[13] F. Surur, Nurul Wahdaniyah dan Miftahul Khaerah, "Konsep Sulapa (Sustainable lanscape planning) di Kawasan Bersejarah Kota Tua Tosora Kabupaten Wajo," dalam Seminar Nasional Sustainable Planning and Culture (SPACE), Bali, 2017.

[14] R. Efendi, B. S. Bahri dan Z. I. Mu Arrif, "Konsep Koperasi Bung Hatta dalam Perspektif Ekonomi Syariah," Jurnal Al Hikmah, vol. 15, no. 1, pp. 111-135, 2018.

[15] Lontara Akkarungeng Wajo I, BPAD Sulsel Koleksi Perpustakaan dan Arsip Daerah Kabupaten Wajo., 1980. 